\title{
BrigitTA Gyimesi
}

Hermeneutical Uncertainty in Postmodern Detective Novels

Pro\&Contra 3

No. 2 (2019) 27-46. 



\section{Abstract}

The search for some form of absolute truth has long been regarded as one of the chief tasks of philosophy, even if there seems to be more validity in maintaining that we inhabit a world devoid of definitiveness, a world lacking a fixed centre where meaning becomes elusive and ambiguous. From the basis that this epistemological plurality is well reflected by textual hermeneutics, I wish to demonstrate how literature provides a means for testing radical (some might say untenable) philosophical positions, in this case uncertainty pushed to its extremes: due to their inherently polysemic nature, texts resist interpretation in the absolute sense and showcase the futility of seeking a definitive meaning. Since truth cannot be said to exist independently of language, it follows that what truth is also varies from subject to subject; truth is a made-up concept of the human mind with linguistic ambiguity playing a crucial role in constructing, interpreting and transmitting such truth.

The fictional equivalent of this approach can be found in the metadetective novels of Paul Auster and Thomas Pynchon: in both City of Glass and The Crying of Lot 49 the protagonists are at pains to unearth a rational and all-encompassing pattern governing reality, with the texts suggesting that such patterns are rather imposed on the outside world than extracted from it. Meaning and truth are revealed to be the mental constructions of a subject reaching arbitrary decisions as to what facts to base their interpretation upon, rendering it nigh impossible to come to a collective and definitive conclusion.

Key words: detective novel, hermeneutics, language, uncertainty

The search for some form of absolute truth has long been regarded as one of the chief tasks of philosophy, even if the existence of such truth has repeatedly and more increasingly been called into question. Although when applied to real-life scenarios and the practical nature of day-to-day reality, the principle of absolute randomness is untenable without descending into chaos, literature offers a platform for philosophical experimentations which can yield insights that would otherwise be very difficult, if not impossible, to obtain. In the present case, the uncertainty and chance coincidences that form the backbone of Thomas Pynchon's The Crying of Lot 49 and Paul Auster's City of Glass are on a level that one cannot plausibly encounter anywhere but in fictive circumstances. The characters are placed in unusual situations to test their skills of interpretation and tolerance of ambiguity - ultimately pushing them beyond breaking point. Readers, in turn, occupy a position analogous to that of the characters: they are expected to navigate the most perplexing of events and engage cognitive capabilities ("detective skills") that would be rarely required in reality.

Oedipa Maas and Daniel Quinn, the protagonists of The Crying of Lot 49 and City of Glass, respectively, are forced to face a radically destabilised reality: they find themselves in 
a world devoid of definitiveness, a world lacking a fixed centre, where meaning becomes elusive and ambiguous: Oedipa is tasked with executing the will of Pierce Inverarity, an immensely wealthy businessman, but (potentially) gets involved in a conspiracy mysteriously referred to as the Tristero; while Quinn is (mistakenly) hired to follow a man named Stillman who purportedly presents a threat to his son. As required of them by their initially straightforward job, the two amateur detectives attempt to unearth a rational and all-encompassing pattern governing reality, but the texts suggest that such patterns are rather imposed on the outside world than extracted from it. Additionally, through the allegory of the maze that manifests itself in the spatial structure of the city, the process of interpretation is shown to be a potentially infinite affair which, as the confused reader will be quick to discover, is strikingly similar to the reading process.

The Crying of Lot 49 and City of Glass are conventionally cast into the category of the metadetective novel. Paralleling the epistemological uncertainty of postmodern reality, the logical and lucid detective stories of the Holmesian type have been replaced by metadetective narratives where attempts at ratiocination, at trying to 'make sense of the world' invariably reveal the futility of such exercises. Through the failure of their detective-characters these texts reject the idea that reality is governed by a hidden but discoverable pattern and highlight the subjective and constructed nature of knowledge. This revelation often culminates in an ontological crisis for the detective as the absence of meaning calls into question and ultimately destroys their reason-based identity, leading to incurable scepticism, self-doubt or outright insanity, where the logicality missing from real life is contortedly restored by fleeing into solipsism. In this manner, what the eponymous "city of glass" promises is not "transparency, but reflection: a city of mirrors that displays its own impenetrability". ${ }^{1}$

Both texts are grounded on a perception of reality that is tacitly understood to be stable and meaningful, even if this meaning is a form of transcendental truth that is not evident at first sight: Quinn denotes this "generalised condition of things as they were" and "the ground on which the happenings of the world took place" with the word fate, ${ }^{2}$ while Oedipa is of the view that "something fast enough, God or a digital machine, might have computed in advance the complex web" of the trajectory of an exploding hair spray can, ${ }^{3}$ and associates the "true" Pacific with a kind of melting pot that "integrated or as-

1 Antoine Dechene, Detective Fiction and the Problem of Knowledge: Perspectives on the Metacognitive Mystery Tale (Cham: Palgrave Macmillan, 2018), 160.

2 Paul Auster, City of Glass (London: Faber and Faber, 2011), 111.

3 Thomas Pynchon, The Crying of Lot 49 (New York: Harper Perennial, 2006), 25. 
sumed the ugliness at any edge into some more general truth". ${ }^{4}$ The crucial point here is that there is a hidden network whose knotty interconnections the perseverant, rational and open-minded inquirer can disentangle and arrive at what would best be termed truth. The initial perception of truth becomes more and more convincing with each subsequent discovery that fits the pattern, as can be seen in Oedipa's case: the more developed the linkage she discovers regarding the Tristero, the more convinced she becomes of its actual existence. But signs, clues and correlations follow all too neatly for unconditionally accepting that the surface faithfully corresponds to the underlying meaning (if there is such a meaning). To put it bluntly, 'it is too good to be true', and both City of Glass and The Crying of Lot 49 indicate that their respective characters might wander too far into the hermeneutical swamps and warn the readers against committing the same mistake. Quinn, when drawing maps of Stillman's daily excursions, is aware of "ransacking the chaos of Stillman's movements for some glimmer of cogency" in order to find a "sense to them, no matter how obscure", admitting that "[p]erhaps he was looking for pictures in the clouds", but then he quickly dismisses his doubts and decides that "the coincidence was too striking" not to be true, thereby pushing him towards an existential crisis ${ }^{5}$. Likewise, in The Crying of Lot 49 the boy band The Paranoids reappears at every twist and turn of the text, with the band's name serving as a convenient warning sign. Moreover, in the second half of the novel there is an allusion to the so-called Scurvhamite sect, who believed that life was "a brute automatism that led to eternal death", but the sect eventually disintegrated "into the gaudy clockwork of the doomed". ${ }^{6}$

That reality does not have an all-explaining reason or purpose to it is illustrated by the contrast between the tightly-knit mystery novel plots conceived by Quinn and his actual foray into the detective business. References to his surprise at how events unfold accompany Quinn's investigation: when Virginia Stillman answers the door for the first time, it is remarked that "[f]or some reason, Quinn had not been expecting this, and it threw him off track"; Stillman Sr's disappearance wrecks his "elaborate and meticulous plans" and it annoys him that "he had not taken this contingency into account"; 8 or when the undercover Quinn meets one of the readers of his books (a scenario that he had often imagined), he finds that he "did not like the girl sitting next to him, and it offended him that she should be casually skimming the pages" of his novel. ${ }^{9}$ As opposed

\footnotetext{
4 Pynchon, The Crying of Lot 49, 41.

5 Auster, City of Glass, 68-70.

6 Pynchon, The Crying of Lot 49, 128.

7 Auster, City of Glass, 13.

8 Auster, City of Glass, 87.

9 Auster, City of Glass, 53.
} 
to the well-plotted narratives Quinn has been writing, his (and, by extension, the reader's) continuously shattered expectations imply that the dominating factor in organising and comprehending reality is not rationality but chance. The leading role chance plays in City of Glass is foregrounded in the opening paragraph when Quinn's purely accidental recruitment is disclosed:

It was a wrong number that started it, the telephone ringing three times in the dead of night, and the voice on the other end asking for someone he was not. Much later, when he was able to think about the things that happened to him, he would conclude that nothing was real except chance. But that was much later. In the beginning, there was simply the event and its consequences. ${ }^{10}$

The fact that Quinn eventually realises the unpredictability of reality is in contrast to what one would expect from a detective novel where, come the dénouement, the superficially disconnected facts and clues are pierced together by the reasoning mind of the detective, offering a holistic explanation of the events and restoring order into chaos. But City of Glass shows that "an event that is pure chance can neither be predicted by prior events nor prefigure subsequent events. Retrospection, which establishes causal connections from a perspective outside or beyond the events themselves, stumbles over a chance event". ${ }^{11}$ A fitting example for the incalculability of reality, for "the contingent occurrence" which in Auster's novels is "a constant and intrusive presence in human existence", ${ }^{12}$ is when Quinn is waiting for Stillman to arrive at the railway station so that he can start following him. No sooner had he caught sight of a man he reckoned to be Stillman than he spotted another Stillman, whose "face was the exact twin" but whose "actions were clearly independent" of the first man, compelling Quinn to an immediate decision as to how to proceed. He instantly realises that

[t]here was nothing he could do now that would not be a mistake. Whatever choice he made — and he had to make a choice — would be arbitrary, a submission to chance. Uncertainty would haunt him to the end. At that moment, the two Stillmans started on their way again. The first turned right, the second turned left. Quinn craved an amoeba's body, wanting to cut himself in half and run off in two directions at once. ${ }^{13}$

\footnotetext{
${ }^{10}$ Auster, City of Glass, 3.

${ }^{11}$ Madeleine Sorapure, "The Detective and the Author: City of Glass," in Beyond the Red Notebook: Essays on Paul Auster, ed. Dennis Barone (Pennsylvania: University of Pennsylvania Press, 1996), 74.

12 Brendan Martin, Paul Auster's Postmodernity (London and New York: Routledge, 2008), 103.

13 Auster, City of Glass, 55-56.
} 
Although by the end of the book Quinn has become practically insane by both attempting to find connections where there are none and by his propensity to overanalyse, in the initial stages he seems to doubt even the existence of a case to be solved: when all Stillman appears to be doing is wandering aimlessly and picking up random, discarded items from the ground, the thought creeps into Quinn's mind that "Stillman was a crazy old man who had forgotten his son. He could be followed to the end of time, and still nothing would happen". ${ }^{14}$ Yet, fuelled by his belief "that human behaviour could be understood, that beneath the infinite facade of gestures, tics and silences, there was finally a coherence, an order, a source of motivation", ${ }^{15}$ he presses on and coerces himself into inventing and accepting ever more strained theories concerning Stillman's motives and purposes. But little by little he is forced to capitulate and acknowledge the incorrectness of his perception of a rational, rule-obeying reality: "Quinn was nowhere now. He had nothing, he knew nothing, he knew that he knew nothing [...] This is New York, and tomorrow will be June third. If all goes well, the following day will be the fourth. But nothing is certain". ${ }^{16}$

Questioning even the orderly succession of days is a long way off from the original premise of a stable reality and this in turn suggests that the ideal of a form of absolute knowledge is unattainable; upon losing Stillman, it dawns on Quinn that he "could walk through the streets every day for the rest of his life, and still he would not find him. Everything had been reduced to chance, a nightmare of numbers and probabilities". ${ }^{17}$ The Crying of Lot 49 also frequently resonates with the ideas proposed in City of Glass that behind the "clues" and appearances there might be nothing to discover: Oedipa is hunting in public toilets for the muted post horn symbol with the aim of confirming the hypothesis she has established about the Tristero, but "all the walls, surprisingly, were blank. She could not say why, exactly, but felt threatened by this absence of even the marginal try at communication latrines are known for". ${ }^{18}$

Both Quinn and Oedipa go to extremes to "create a teleological narration", stubbornly suppressing their doubts that reality might be "determined by chance, that is, by the absence of signification". ${ }^{19}$ They hold the traditional view that a) there is always a one-to-one correspondence between signified and signifier, and that b) signs are created for the purposes of communication and that they have inherent meaning. Oedipa

\footnotetext{
${ }^{14}$ Auster, City of Glass, 64.

${ }^{15}$ Auster, City of Glass, 67.

${ }^{16}$ Auster, City of Glass, 104.

${ }^{17}$ Auster, City of Glass, 91.

${ }^{18}$ Pynchon, The Crying of Lot 49, 53.

${ }^{19}$ Dechene, Detective Fiction and the Problem of Knowledge, 162.
} 
believes that things possess "a hieroglyphic sense of concealed meaning, of an intent to communicate", ${ }^{20}$ and the text's abundant allusions to couriers, messengers and secret channels of communication seemingly reinforce this aspect. However, the ironic name of the underground mailing system-WASTE_-and the method of posting letters by dropping them into designated trash cans indicate it may be a waste of time and effort to ascribe to them any definitive meaning or objective existence. Indeed, the playful subversion of well-known acronyms highlights the arbitrary nature of signs: in The Crying of Lot 49, CIA stands for Conjuration de los Insurgentes Anarquistas, ${ }^{21}$ ACDC is short for Alameda County Death Cult, ${ }^{22}$ and NADA, the name of a car dealership and Spanish for 'nothing', concentrates the text's infinite ambiguity into a paradox that is both a symbol and an antisymbol. Pynchon's use of such "shifting metaphors - typical of the novel's discourse - destabilise [Oedipa's] terrain while simultaneously tantalising her (and the reader) with its interconnections". ${ }^{23}$ The names of characters function along the same line, a rather obvious one being our heroine, Oedipa, whose name immediately recalls the story of Oedipus and thus links Oedipa to that family of characters who 'specialise' in solving puzzles and crimes. ${ }^{24}$ But perhaps the prime example for the proliferation of meanings and references is the muted post horn symbol, which "break[s] with every given context and engender $[\mathrm{s}]$ infinitely new contexts in an absolutely nonsaturable fashion" 25 to such an extent that it essentially loses its signifying capacity.

If it cannot be proved that a given sign exclusively corresponds to a given meaning, there can be no fixed ground for interpretation either. The ever-increasing number of signs that according to Oedipa are all linked to the Tristero are never definitively classified as really meaningful, pretending to be meaningful or not being meaningful at all, leaving Oedipa (and the helpless reader) with essentially three options - the Tristero really exists, the Tristero is a hoax or prank orchestrated by Inverarity at Oedipa's expense, or Oedipa is hallucinating everything - the validity of all of which could credibly be argued for. Oedipa's task is then made significantly harder by the fact that not only the evidence related to this supposed conspiracy and the role of the people she meets require interpretation, but

${ }^{20}$ Pynchon, The Crying of Lot 49, 14.

${ }^{21}$ Pynchon, The Crying of Lot 49, 96.

${ }^{22}$ Pynchon, The Crying of Lot 49, 99.

${ }^{23}$ David Seed, "Media Systems in The Crying of Lot 49," in American Postmodernity: Essays on the Recent Fiction of Thomas Pynchon, ed. Ian D. Copestake (Bern: Peter Lang, 2003), 23.

${ }^{24}$ Seed, "Media Systems in The Crying of Lot 49," 29.

${ }^{25}$ Jacques Derrida, "Signature Event Context," in Margins of Philosophy, trans. Alan Bass (Chicago: The University of Chicago Press, 1982), 320.

Pro\&Contra 2 (2019) 27-46. 
the nature and even the existence of the conspiracy cannot be verified either. ${ }^{26}$ By refusing to play the arbiter, the text allows for and encourages hermeneutical undecidability where even the most contradictory oppositions can coexist, an experience familiar to Quinn as well who cannot decide once and for all whether Stillman is a cunning criminal to be kept an eye on or just a harmless old philosopher collecting junk. Oedipa and Quinn are "confronted with the impossibility of finding physical evidence or reliable truths to support their hypotheses and explain what, in fact, appears to be merely arbitrary or subject to endless doubt", ${ }^{27}$ and neither of them can endure this state of indeterminacy with cheerful nonchalance for long. Quinn opts for self-delusion rather than admitting he might be a fool, and persuades himself "[h]ow much better it was to believe that all [Stillman's] steps were actually to some purpose"; ${ }^{28}$ promptly, just when he most needed it, he 'discovers' that Stillman's daily wanderings spell out the words 'the tower of Babel'. ${ }^{29}$ Oedipa, on the other hand, flirts with the idea of self-induced solipsism ("Shall I project a world?") or even hopes she has gone "mentally ill" in order to fend off the "revelations which now seemed to come crowding in exponentially" and to escape the chilling fact that "[t]here was nobody who could help her. Nobody in the world. They were all on something, mad, possible enemies, dead". ${ }^{30}$

The word "possible" with its disquieting consequences is perhaps the most important concept of the texts, both of which make liberal use of modals, conditionals and hypothetical expressions. The characters' attempts at getting rid of the 'un-' in 'uncertainty' drive the plots forward: in City of Glass, whether Stillman is a criminal, or whether Quinn started to follow the right Stillman in the first place, and in The Crying of Lot 49, whether the Tristero really exists or Oedipa is merely pursuing hallucinations. The latter text, for instance, offers a carefully devised array of genuine, potential and invented clues as to the existence of the Tristero system, with references to the historical Thurn und Taxis post service at one end of the spectrum, and the allegation that the Tristero's wish to abolish postal monopoly was the cause of the French Revolution at the other. The texts, however, by opposing the linear narration of detective fictions and "mak[ing] lateral moves where resemblances proliferate", ${ }^{31}$ cruelly cheat those readers who expect a final solution: similarly to the main characters, they will be left in a continual state of uncertainty, haunted by a multitude of possibilities that,

\footnotetext{
${ }^{26}$ Brian McHale, Postmodernist Fiction (London and New York: Routledge, 1987), 22.

${ }^{27}$ Dechene, Detective Fiction and the Problem of Knowledge, 28.

28 Auster, City of Glass, 61.

29 Auster, City of Glass, 70.

${ }^{30}$ Pynchon, The Crying of Lot 49, 64, 141.

${ }^{31}$ Seed, "Media Systems in The Crying of Lot 49," 25.
} 
because any "revelation it would imply would also entail a collapse or mutation of the novel's fundamental structure of doubt and deferral", ${ }^{32}$ will never solidify into actualities. Their experience will reflect that of Oedipa, who founds her investigation on an idiosyncratic performance of a revenge tragedy and especially on its last two lines which later turn out to come from the "doubtful Whitechapel version" that "abounds in such corrupt and spurious lines" that makes it "hardly to be trusted". ${ }^{33}$ Furthermore, the reaction of the readers to the prospect that the text intentionally 'makes no sense' may parallel Oedipa's. When she is confronted with the question if it ever crossed her mind that everything might be a hoax, the text says: "It had occurred to her. But like the thought that someday she would have to die, Oedipa had been steadfastly refusing to look at that possibility directly, or in any but the most accidental of lights. 'No,' she said, "that's ridiculous.". ${ }^{34}$ But she will always harbour doubts as to the veracity of any interpretation, knowing well that "[b]ehind the hieroglyphic streets there would either be a transcendent meaning or only the earth [...] another mode of meaning behind the obvious, or none. Either Oedipa in the orbiting ecstasy of a true paranoia, or a real Tristero". ${ }^{35}$ She is aware that all her efforts might only yield "compiled memories of clues, announcements, intimations, but never the central truth itself" 36 and she recognises the dangerous seduction of meaning-hunting because of "the way it fitted, logically, together". ${ }^{37}$ Yet there is always a what if, and this what if motivates Oedipa to continue her investigation, and the same what if propels Oedipa to attend the auction of the forged stamp collection at the end of The Crying of Lot 49.

In many respects, City of Glass operates alongside the same principles of ambiguity as The Crying of Lot 49, but here there is another layer of uncertainty of a more narratological kind. With approximately 20 pages left, we are met with a curious passage:

A long time passed. Exactly how long it is impossible to say. Weeks certainly, but perhaps even months. The account of this period is less full than the author would have liked. But information is scarce, and he has preferred to pass over in silence what could not be definitely confirmed. Since this story is based entirely on facts, the author feels it his duty not to overstep the bounds of the verifiable, to resist at all costs the perils of invention. Even

\footnotetext{
32 John Johnston, "Toward the Schizo-Text: Paranoia as Semiotic Regime in The Crying of Lot 49," in New Essays on The Crying of Lot 49, ed. Patrick O’Donnell (Cambridge: Cambridge University Press, 1991), 68.

33 Pynchon, The Crying of Lot 49, 81-82.

${ }^{34}$ Pynchon, The Crying of Lot 49, 138.

35 Pynchon, The Crying of Lot 49, 150-151.

${ }^{36}$ Pynchon, The Crying of Lot 49, 76.

${ }^{37}$ Pynchon, The Crying of Lot 49, 33.
} 
the red notebook, which until now has provided a detailed account of Quinn's experiences, is suspect. ${ }^{38}$

And a little later:

It was some time in mid-August when Quinn discovered that he no longer could hold out. The author has confirmed this date through diligent research. It is possible, however, that this moment occurred as early as late July, or as late as early September, since all investigations of this sort must make allowances for a certain margin of error. But, to the best of his knowledge, having considered the evidence carefully and sifted through all apparent contradictions, the author places the following events in August, somewhere between the twelfth and twenty-fifth of the month. ${ }^{39}$

As if things have not been complicated enough, the so-far conventional omniscient narration is revealed to be epistemologically doubtful. The very last pages of the novel show that the entire preceding story has been a speculation of an unnamed friend of the fictional Auster on the basis of Quinn's red notebook and Auster's conversation with him. Since he does not possess any first-hand experience of the events, it becomes impossible to decide which pieces of information can be trusted, which are the hard facts originating from Quinn's records and which issue merely from the narrator's imagination, and this obscurity pertains not only to "tying up loose ends and resolving marginal issues", but also to "decisive questions" and "crucial matters in the context of the detective story he writes". ${ }^{40}$ The narrator seems at pains to retrospectively justify his chosen method of narration as a form of recompense for deceiving the readers for so long: he declares that following Quinn's disappearance it "would be foolish even to hazard a guess" as to what might have happened to him ${ }^{41}$ and appeals to the reader's empathy and intellectual pride: "There were moments when the text was difficult to decipher, but I have done my best with it and have refrained from any interpretation. The red notebook, of course, is only half the story, as any sensitive reader will understand". ${ }^{42}$ With this last statement, he implicitly acknowledges that he has filled in the numerous blanks left by Quinn's notebook with his own ideas and imaginary scenarios, in hindsight bestowing a distinctly different quality on earlier remarks such as this one near the beginning of the text: "Like so many

\footnotetext{
38 Auster, City of Glass, 114.

39 Auster, City of Glass, 119.

${ }^{40}$ Sorapure, "The Detective and the Author," 75.

${ }^{41}$ Auster, City of Glass, 132.

${ }^{42}$ Auster, City of Glass, 133.
} 
of the things that happened to him over the days and weeks that followed, Quinn could not be sure of any of it", ${ }^{43}$ where the name of Quinn could easily be substituted for the "I" of the narrator.

A similar situation arises in The Crying of Lot 49 if we recall that the reader is not granted access to the text of The Courier's Tragedy, the revenge tragedy that forms the basis of Oedipa's investigation, but only hears about it through the mediation of other characters who, for all we know, might misremember or misquote the play. ${ }^{44}$ We furthermore have to question Oedipa's reliability who, despite being the novel's main focaliser, often displays unreliability and a "dangerous capacity for solipsism, her tendency to believe that the external world has been fabricated by her own mind". 45 The inherent and inevitable uncertainty present in all acts of narration exposes the subjective element in truth and implies that truth, as opposed to something passive waiting to be discovered by anyone caring enough for such matters, is a mental concept produced by human consciousness. Randolph Driblette, the director responsible for staging The Courier's Tragedy, seems to adhere to these principles when he lectures Oedipa on the 'meaning' of his stage representation while taking a shower:

If I were to dissolve in here - speculated the voice out of the drifting stream -, be washed down the drain into the Pacific, what you saw tonight would vanish too [...] You can put together clues, develop a thesis, or several, about why characters reacted to the Trystero possibility the way they did, why the assassins came on, why the black costumes. You could waste your life that way and never touch the truth. Wharfinger supplied words and a yarn. I gave them life. That's it. ${ }^{46}$

It is evident in her later reflections upon her encounter with a homeless sailor that Oedipa internalised Driblette's message ("It astonished her to think that so much could be lost, even the quantity of hallucination belonging just to the sailor that the world would bear no further trace of"), but she takes a further step and links this invisible truth to language: "She knew, because she had held him, that he suffered DT's. Behind the initials was a metaphor [... which] was a thrust at truth and a lie, depending where you were [...] She knew that the sailor had seen worlds no other man had seen if only because there was that high magic to low puns..." ${ }^{47}$ Oedipa realises that there is an intimate connection

\footnotetext{
43 Auster, City of Glass, 30.

${ }^{44}$ Seed, "Media Systems in The Crying of Lot 49," 30.

45 McHale, Postmodernist Fiction, 23.

46 Pynchon, The Crying of Lot 49, 62-63.

${ }^{47}$ Pynchon, The Crying of Lot 49, 104-5.
} 
between linguistic and external meaning, between language and knowledge, a revelation which is also shared by Quinn in City of Glass. Since he is an author of mystery novels, his penchant for writing can safely be presupposed, but that he attributes a substantial amount of importance to writing and language becomes manifest when he buys the notorious red notebook for the Stillman case, with the narrator remarking that "[i]t would be helpful to have a separate place to records his thoughts, his observations, and his questions. In that way, perhaps, things might not get out of control". ${ }^{48}$ Writing as a means of organising and solidifying knowledge appears again when Quinn, in one of his bouts of despair on account of not progressing with the case, briefly entertains the thought of stealing Stillman's own notebook and thus of securing invaluable and otherwise unattainable knowledge. But the firmest indication of how much words mean to Quinn comes at the end when, in his self-inflicted exile in an empty room, he spends all his waking days with trying to jot down all the epiphanies crossing his mind, with his identification of life with language evolving to such an extreme level that his last sentence is "[w]hat will happen when there are no more pages in the red notebook?". ${ }^{49}$ Bearing in mind Quinn's eventual fate, however, writing was not the answer to the question of how to organise knowledge and arrive at the final truth.

The connection between language and reality becomes a central topic in City of Glass chiefly through Stillman's elaborately explained philosophical theory, according to which not only the failures of Quinn and his detective kindred, but also all the indeterminacy and arbitrariness in life may be encoded in the semantic structure of language itself. Stillman's main tenet is the representational incapability of linguistic signs, the cause of which he locates in the Fall of Man: he claims that whereas the original language of Paradise directly referred to the objects in themselves and thus carried truth value, after the Fall Satan's language, which he characterises as ambiguous and misleading, replaced this original language and has remained in use ever since. Polysemy has become an intrinsic part of linguistic signs, and since language is our quasi-exclusive means of conveying truth and knowledge, it is subject to incessant and infinite misunderstandings, promoting uncertainty and hindering our apprehension of reality per se. Stillman holds the view that the "clue to our salvation" and to truth is "to become masters of the words we speak, to make language answer our needs", ${ }^{50}$ i.e. without restoring the referential potential of God's language, we have no chance of obtaining genuine truth and "we will continue to

\footnotetext{
48 Auster, City of Glass, 38.

${ }^{49}$ Auster, City of Glass, 132.

${ }^{50}$ Auster, City of Glass, 81.
} 
be lost". ${ }^{51}$ Language as essentially a fossilised tool; this might remind one of a well-known forerunner, Friedrich Nietzsche, who defines truth in linguistic terms as well. For him, truth is a "movable host of metaphors, metonymies and anthropomorphisms [...] truths are illusions which we have forgotten are illusions; they are metaphors that have become worn out and have been drained of sensuous force [... telling truths] is the duty to lie according to a fixed convention", 52

Apparently, there is a strong connection between language and truth, and indeed the ways and methods of understanding texts are not too dissimilar to comprehending reality. For the reading process, Wolfgang Iser developed the concept of the 'blank', a gap in the text that provides the stimulus for forming hypotheses regarding the underlying meaning of the text, the latent potential that, because it entirely depends on the reader's hermeneutical capacities, is responsible for the emergence of individual interpretations. ${ }^{53}$ It is important to note that since blanks are invisible on the textual surface, the reader's active participation is indispensable to the construction of meaning; the "text's intention" cannot be located in the printed words alone, but "[o]ne has to decide to 'see' it. Thus it is possible to speak of the text's intention only as the result of a conjecture on the part of the reader". ${ }^{54}$ A consequence of the unique predispositions and capacities of readers coupled with the linguistic polysemy inherent in all texts is that texts resist definitive interpretation, i.e. there is no absolute truth that can be extracted from them. This model of reading and meaning-generation resembles the process by which humans approach the world: we tend to approach reality as possessing, deep down, some hidden truth—some blanks waiting to be actualised-when in fact the 'meaning of life' is purely our projection, our idiosyncratic attempts at comprehending reality. Just as we expect texts to be coherent, unified wholes whose "message" can be understood, we refuse to look at the world as an essentially meaningless place whose main governing principle is randomness. But metadetective novels confront us with exactly this possibility, with a world where "detectives cannot detect, where investigation brings only questions, where reason brings absurdity and where end is no closure". 55

${ }^{51}$ Auster, City of Glass, 78.

${ }^{52}$ Friedrich Nietzsche, "On the Truth and Lies in a Nonmoral Sense," in Philosophy and Truth: Selections from Nietzsche's Notebooks of the early 1870s, ed. and trans. Daniel Breazeale (New Jersey: Humanities Press International, 1992), 84.

${ }^{53}$ Wolfgang Iser, The Act of Reading: A Theory of Aesthetic Response (Baltimore: The Johns Hopkins University Press, 1980), 167.

${ }^{54}$ Umberto Eco, "Overinterpreting Texts," in Interpretation and Overinterpretation, ed. Stefan Collini (Cambridge: Cambridge University Press, 1992), 64.

${ }^{55}$ Michael Cook, Narratives of Enclosure in Detective Fiction: The Locked Room Mystery (Basingstoke: Palgrave Macmillan, 2011), 151. 
It may be no coincidence, then, that Jorge Luis Borges, whom some consider an early forerunner of the postmodern detective stories, imagines humanity's quest for the final truth to take place in a labyrinthine library, where all books refer to other books in an infinite and potentially circular chain. The labyrinth as a hermeneutical symbol is rather apt as it can, and in metadetective novels it frequently does, represent both the text and the city where the investigation occurs, firmly linking together language and reality. Both The Crying of Lot 49 and City of Glass are concerned with "urban hieroglyphics" where mental activities like interpretation and puzzle-solving acquire a spatial dimension by their association with walking and travelling: ${ }^{56}$ Oedipa collects more and more evidence for the existence of a secret communicational network while visiting the late Inverarity's properties spread throughout California, whereas Quinn tries to understand Stillman's motives by following him through the streets of New York and 'reading' the maps of his excursions. The city thus represents the human mind in its externalised form where connections are drawn and signs are interpreted but, if we stick to the maze metaphor, it is also a space where getting lost is easier than locating the centre or attaining a holistic overview of the system. The postmodern notion of the rhizome may be an even more fitting metaphor here: a rhizome is a neverending network where everything is interconnected with everything else and where "every local description tends to be a mere hypothesis about the network as a whole. Within the rhizome, thinking means feeling one's way, in other words, by conjecture". ${ }^{57}$ For Quinn, New York (and ultimately his own mind) becomes a rhizome of infinite possibilities and consequently with no escape, a prospect that is already foreshadowed in the very first pages of the novel: "New York was an inexhaustible space, a labyrinth of endless steps [... which] always left him with the feeling of being lost [...] New York was the nowhere he had built around himself, and he realised that he had no intention of ever leaving it again". ${ }^{58}$ Indeed, during the course of his investigation Quinn soon finds out that New York is a "labyrinthine city of words in which signifiers can only refer to other signifiers", never touching the essence of things. ${ }^{59}$ Perhaps it is no wonder that Stillman chose this gigantic mess of a metropolis, this "inexhaustible storehouse of shattered things" where the "disarray is universal", ${ }^{60}$ as a starting point for his mission of repairing the broken relationship between language and reality. The Crying of Lot 49 also thematises infrastructure systems and the urban environment as

\footnotetext{
${ }^{56}$ Dechene, Detective Fiction and the Problem of Knowledge, 162.

${ }^{57}$ Umberto Eco, From the Tree to the Labyrinth: Historical Studies on the Sign and Interpretation, trans. Anthony Oldcorn (Cambridge: Harvard University Press, 2014), 54-55.

${ }^{58}$ Auster, City of Glass, 3-4.

${ }^{59}$ Dechene, Detective Fiction and the Problem of Knowledge, 163.

60 Auster, City of Glass, 78.
}

Pro\&Contra 2 (2019) 27-46. 
a metaphor for communication and interpretation: Oedipa once associates the layout of a city with the printed circuit of a radio, while the "freeways described in the novel are abstracted into information highways" and provide Oedipa with enough stimulus to forge new theories and expand previous ones. ${ }^{61}$

Since reading bears a striking similarity to investigation, detective novels can be considered allegories for the reading process, with the reader assuming the role of the detective. (Another interesting point is that both our detectives have literary affiliations: Quinn is a mystery writer and Oedipa has a degree in literature, which may render them predestined to deciphering signs.) The reading and detecting processes presuppose a similar mental attitude or disposition insofar as readers and detectives regard each hint and allusion as possibly "pregnant with potential purpose, haloed with a heightened, even hallucinatory, intensity of meaning". ${ }^{62}$ What should not be forgotten, however, is that "[f]acts can acquire meaning only as a function of someone's subjectivity", ${ }^{63}$ i.e. it is the interpreter's sole discretion how they decide to manage a certain piece of information and to what purposes; meaning emerges from subjective powers applied to facts, not from the facts in themselves. Furthermore, usually only those facts are singled out by the interpreter as significant that seem to corroborate their existing beliefs, as attested to by Oedipa:

She had caught sight of the historical marker only because she'd gone back, deliberately, to Lake Inverarity one day, owing to this, what you might have to call, growing obsession, with "bringing something of herself"- - even if that something was just her presence-to the scatter of business interests that had survived Inverarity. She would give them order, she would create constellations. ${ }^{64}$

Oedipa's urge to create parallels the "delight of [...] drawing together what seems disparate and disconnected into a satisfying pattern" exhibited by readers and detectives, with the caveat that meaning-construction is "not an arid analytical exercise but an inspired blend of intuition and imagination", ${ }^{65}$ in other words the product of nearly untraceable cognitive processes. What makes a difference is to what degree a certain interpretation relies on strenuous leaps of faith, with Eco demonstrating the risks of transgressing beyond the limits of the acceptable with the accidental occurrence of the words 'crocodile' and 'while' within the same sentence:

61 Seed, "Media Systems in The Crying of Lot 49," 22.

62 Rita Felski, The Limits of Critique (Chicago: The University of Chicago Press, 2015), 99.

63 David Bleich, Subjective Criticism (Baltimore: The Johns Hopkins University Press, 1981), 28.

64 Pynchon, The Crying of Lot 49, 72.

65 Felski, The Limits of Critique, 108.

Pro\&Contra 2 (2019) 27-46. 
[T] he difference between the sane interpretation and paranoiac interpretation lies in recognising that this relationship is minimal and not, on the contrary, deducing from this minimal relationship the maximum possible [...] the paranoiac is the person who begins to wonder about the mysterious motives that induced me to bring these to particular words together. The paranoiac sees beneath my example a secret, to which I allude. In order to read both the world and texts suspiciously one must have elaborated some kind of obsessive method. ${ }^{66}$

These imaginative games, therefore, can easily and quickly spiral out of control and lead to all sorts of mental disruptions and breakdowns. In City of Glass, Quinn's investigation slowly develops into an obsession, and to the realisation that reality, despite his best efforts to rationalise and regulate it, stubbornly deviates from the traditional, epistemologically-governed model, he responds by pursuing extremely idiosyncratic associations and interconnections, becoming a grotesque version of his fictional detective characters and eventually going insane. In The Crying of Lot 49, the overabundance and especially the radical indeterminacy of signs stretch Oedipa's coping skills to the limit, which brings her latent solipsistic-paranoiac predisposition to the surface. On the one hand, she is aware that she is risking madness if she oversteps certain boundaries ("[She felt] anxious that her revelation not expand beyond a certain point. Lest, possibly, it grow larger than she and assume her to itself" ${ }^{67}$ ), which she nevertheless seems to have done several times already (e.g. "She grew so to expect [the post horn] that perhaps she did not see it quite as often as she later was to remember seeing it" ${ }^{68}$ ). On the other hand, she is willing to and even prefers to embrace insanity ("she wanted it all to be fantasy-some clear result of her several wounds, needs, dark doubles. She wanted Hilarius to tell her she was some kind of a nut and needed a rest, and that there was no Trystero" ${ }^{69}$ ) if that entails the eradication of or at least a substantial reduction in the state of uncertainty she is in, which she finds so unbearable that she contemplates suicide, as she confesses to one of the supposed accomplices in the supposed conspiracy: " $[\mathrm{t}$ may be a practical joke for you, but it stopped being one for me a few hours ago. I got drunk and went driving on these freeways. Next time I may be more deliberate" ${ }^{\text {. }}$.

Fittingly, Oedipa receives a rather cryptic reply which nevertheless does not discourage her from attending the auction of lot 49, the 'Tristero stamps'. In sharp contrast to Quinn who disappears without a trace, Oedipa at least seems to come to terms with cold

66 Eco, "Overinterpreting Texts," 48.

67 Pynchon, The Crying of Lot 49, 137.

68 Pynchon, The Crying of Lot 49, 100.

69 Pynchon, The Crying of Lot 49, 107.

70 Pynchon, The Crying of Lot 49, 146.

Pro\&Contra 2 (2019) 27-46. 
reality: that as opposed to being something ready-made waiting to be discovered, truth is a made-up concept of the human mind and linguistic ambiguity plays a crucial role in constructing, interpreting and transmitting it. While the familiar reasoning methodology of Sherlock Holmes "implies a perfect convergence of language and reality, in which signifiers and signifieds connect clearly and deliver a transparent, empirically verifiable narrative", ${ }^{71}$ the "inadequacy of language to make sense of the world", a common theme in metadetective novels, subverts the rationalising tendencies prevalent in detective stories, "reveal[ing] the extent of the artifice involved in maintaining its narrative form" ${ }^{72}$ As demonstrated within The Crying of Lot 49 and City of Glass, literature provides an excellent platform for radical thought experiments, especially of the hermeneutic type: due to their inherently polysemic nature, texts resist interpretation in the absolute sense and showcase the futility of searching for definitive meaning. This becomes even more emphatic if we take a look at the conclusions of the texts, which could hardly be called the resolution that readers expect from a narrative: the plot of The Crying of Lot 49 is abruptly cut off exactly at the point when the existence of the Tristero would finally be either affirmed or debunked, leaving the reader with their own personal projections; whereas in City of Glass the sudden appearance of another ontological layer in the form of an unreliable narrator means that the reader finishes the book with more unanswered questions than the moreor-less conventional beginning of the story would have predicted. Besides these possibly underwhelming, unresolved endings, in both novels the epistemological uncertainties and the labyrinths of real or imagined signs cause the protagonists (and perhaps even some readers) to experience episodes of paranoia, as if the multitude of interpretive options lying before them were a dangerous and maddening prospect, and the slippery fabric of the texts does nothing to clarify the result or indeed the rationale of their mission.

${ }^{71}$ Dechene, Detective Fiction and the Problem of Knowledge, 163.

${ }^{72}$ Cook, Narratives of Enclosure in Detective Fiction, 144. 


\section{References}

Auster, Paul. City of Glass. In The New York Trilogy. London: Faber and Faber, 2011.

Bleich, David. Subjective Criticism. Baltimore: The Johns Hopkins University Press, 1981.

Cook, Michael. Narratives of Enclosure in Detective Fiction: The Locked Room Mystery. Basingstoke: Palgrave Macmillan, 2011.

https://doi.org/10.1057/9780230313736

Dechene, Antoine. Detective Fiction and the Problem of Knowledge: Perspectives on the Metacognitive Mystery Tale. Cham: Palgrave Macmillan, 2018.

https://doi.org/10.1007/978-3-319-94469-2

Derrida, Jacques. "Signature Event Context." In Margins of Philosophy, 309-30. Translated by Alan Bass. Chicago: The University of Chicago Press, 1982.

Eco, Umberto. From the Tree to the Labyrinth: Historical Studies on the Sign and Interpretation. Translated by Anthony Oldcorn. Cambridge: Harvard University Press, 2014.

https://doi.org/10.4159/9780674728165

Eco, Umberto. "Overinterpreting Texts." In Interpretation and Overinterpretation, edited by Stefan Collini, 45-66. Cambridge: Cambridge University Press, 1992.

https://doi.org/10.1017/CBO9780511627408.003

Felski, Rita. The Limits of Critique. Chicago: The University of Chicago Press, 2015. https://doi.org/10.7208/chicago/9780226294179.001.0001

Iser, Wolfgang. The Act of Reading: A Theory of Aesthetic Response. Baltimore: The Johns Hopkins University Press, 1980.

Johnston, John. "Toward the Schizo-Text: Paranoia as Semiotic Regime in The Crying of Lot 49." In New Essays on The Crying of Lot 49, edited by Patrick O'Donnell, 47-78. Cambridge: Cambridge University Press, 1991. https://doi.org/10.1017/CBO9780511620461.004

Martin, Brendan. Paul Auster's Postmodernity. London and New York: Routledge, 2008. https://doi.org/10.4324/9780203937518

McHale, Brian. Postmodernist Fiction. London and New York: Routledge, 1987. 
Nietzsche, Friedrich. "On the Truth and Lies in a Nonmoral Sense." In Philosophy and Truth: Selections from Nietzsche's Notebooks of the early 1870s, edited by Daniel Breazeale, 79100. Translated by Daniel Breazeale. New Jersey: Humanities Press International, 1992.

Pynchon, Thomas. The Crying of Lot 49. New York: Harper Perennial, 2006.

Seed, David. "Media Systems in The Crying of Lot 49." In American Postmodernity: Essays on the Recent Fiction of Thomas Pynchon, edited by Ian D. Copestake, 15-34. Bern: Peter Lang, 2003.

Sorapure, Madeleine. "The Detective and the Author: City of Glass." In Beyond the Red Notebook: Essays on Paul Auster, edited by Dennis Barone, 71-87. Pennsylvania: University of Pennsylvania Press, 1996.

https://doi.org/10.9783/9780812206685.71 